\title{
SQUAMOUS METAPLASIA WITH MULTIPLE EPIDERMAL CYSTS IN FIBROADENOMA: A CASE REPORT
}

R. K. Chandrakar ${ }^{1}$, Chandni Krishnani2 ${ }^{2}$ Nidhi Rai ${ }^{3}$, Yogesh Pawde ${ }^{4}$, Manoj Malpani ${ }^{5}$

\section{HOW TO CITE THIS ARTICLE:}

R. K. Chandrakar, Chandni Krishnani, Nidhi Rai, Yogesh Pawde, Manoj Malpani. "Squamous Metaplasia with Multiple Epidermal Cysts in Fibroadenoma: A Case Report". Journal of Evolution of Medical and Dental Sciences 2015; Vol. 4, Issue 45, June 04; Page: 7852-7855, DOI:10.14260/jemds/2015/1144

\begin{abstract}
Fibroadenoma is one of the most common cause of benign lump in breast. But presence of squamous metaplasia and multiple epidermal cysts in fibroadenoma is very rare. Here in we describe a case of 40 years old female presented with breast lump who had undergone lumpectomy. The lump was well encapsulated with presence of multiple tiny chalky white areas in the otherwise lobulated glistening white nodule. On microscopy the nodule was fibroadenoma with multiple epidermal cysts and few areas of squamous metaplasia.
\end{abstract}

KEYWORDS: Epidermal cyst, Fibroadenoma, Squamous Metaplasia.

INTRODUCTION: Fibroadenoma is common benign breast lesion more common in young age group, but can occur in older women as well.[1] Several changes occur within epithelial element of fibroadenoma, including apocrine metaplasia and varying degrees of epithelial hyperplasia, Apocrine metaplasia is a fairly frequent component of fibroadenoma; however, fibroadenoma with squamous metaplasia is a rare entity.[2] Associated epidermal cyst in fibroadenoma of breast is also very rare.[3]

CASE REPORT: We report a case of 40 years old female who presented with a solitary, firm, mobile lump in the subareolar region of right breast of 2 years duration. We received the lumpectomy specimen for histopathological examination. On gross inspection lump was encapsulated, measuring $4.0 \times 4.0 \times 3.0 \mathrm{~cm}$ and globular. Cut surface was slightly lobulated, grayish white glistening with multiple chalky white areas of $1 \mathrm{~mm}$ to $3 \mathrm{~mm}$ in size [Figure 1]. Multiple representative Haematoxylin \& Eosin stained sections showed loose cellular stromal connective tissue surrounding variable number of ductular structures. The stromal nuclei were spindle shaped with little pleomorphism and infrequent mitosis. The ductal component was lined by cuboidal to low columnar cells with round uniform nuclei resting on a myoepithelial cell layer. A few ducts were dilated and lined by multilayered squamous epithelium [Figure 2]. Sections from the chalky white areas revealed cysts lined by mature stratified squamous epithelium filled with anucleate squames and keratin [Figure 3]. Surrounding stroma showed dense chronic nonspecific inflammatory infiltrate predominantly lymphocytes. We reported the case as fibroadenoma with squamous metaplasia and multiple epidermal cysts.

DISCUSSION: Epidermal inclusion cysts are common cutaneous cyst lesions and have been found in various parts of the body that are usually located in the face, scalp, neck and trunk. Only a few cases of epidermal cysts of breast have been reported in literature, ${ }^{[4]}$ and very few in fibroadenoma. Fibroadenoma is the most common benign breast disease in adolescent and young women and tends to regress as the age of patient increases. Fibroadenoma arises as a result of an abnormal proliferation and involution of breast due to hormonal fluctuation and are not truly neoplastic.[5] These tumors are usually composed of glandular and connective tissue elements. The appearance varies from case to 
case, depending on the relative amount of the two components. The tubules are lined by cuboidal or low columnar cells with round uniform nuclei resting on a myoepithelial cell layer. The stroma is made up of loose connective tissue rich in acid mucopolysachharides. Morphological changes found in fibroadenoma are hyalinization, calcification, ossification and presence of a reactive type of multinucleated giant cells.[6]

There is no definitive understanding of how epidermal inclusion cyst and squamous metaplasia actually develop. One theory is that it may be created by squamous metaplasia of normal columnar cells within a dilated duct in the case of fibrocystic disease or in fibroadenoma or phylloides tumor.[7] Another theory is that the squamous changes in the breast probably begin within the myoepithelial cell layer, before eventually involving the entire acinus. Squamous metaplasia of breast may result from myoepithelial cell differentiation in a manner analogous to the development of squamous lesion in the uterine cervix and salivary gland.[8] The myoepithelial cell origin of the metaplastic squamous cells is supported by the histological findings of transition between myoepithelial cells and squamous cells along with immunohistochemical expression of actin, vimentin and S-100 protein in the metaplastic squamous cells support.[9]

As squamous metaplasia is not common in fibroadenoma, Phylloides tumor may be considered when there is abundant squamous metaplasia in a background of fibroepithelial neoplasm that demonstrates stromal hyper cellularity and a leafy pattern.[10]

In conclusion, epidermal cyst and squamous metaplasia even though it is not common, is found in fibroadenoma as reported in present case.

\section{REFERENCES:}

1. Hunter BT, Roberts CC, Hunt KR, Fajardo LL. Occurrence of fibroadenoma in postmenopausal women referred for breast biopsy. J Ageing Geriatr 1996; 44: $61 \pm 4$.

2. Azzopardi JG, Ahmed A, Millis RR. Problems in breast pathology. London: Saunders. 1979: 3940.

3. Jung Jong-Jae, Lee Ji-Shin, Yang Hyun-Seung Fibroadenoma with formation of epidermal cyst- A case report, Korean J Path ol 2000; 34: 537-539.

4. Lam SY, Kasthoori JJ, Mun KS, Rahmat K. Epidermal inclusion cyst of the breast: a rare benign entity. Singapore Med J. 2010; 51: e191-4.

5. Dent DM, Cant PJ. Fibroadenoma World J Surg 1989; 13: 706-10.

6. Borean K, Tron VA, Churg A, Clement PB. Mammary fibroadenoma with multinucleated stromal giant cells. Am J Surg Pathol 1986; 10(11): 823.7.

7. Chantra PK, Tang JT, Stanley TM, Bassett LW. Circumscribed fibrocystic mastopathy with formation of an epidermal cyst. Am J Roentgenol. 1994; 163: 831-2.

8. Reddick RL, Jennette JC, Askin FB. Squamous metaplasia of breast. An ultrastructual and immunological evaluation. Am J Clin Pathol 1985 Oct; 84(4): 530-3.

9. Raju GC. The histological and Immunohistochemical evidence of squamous metaplasia from myoepithelial cells in the breast. Histopathology 1990; 17: 272-5.

10. Rosai J. Rosai \& Ackerman's Surgical Pathology. St Louis; Mosby 2004: 1771. 


\section{CASE REPORT}

Figure1: Gross Pathology; Well encapsulated mass with tiny cystic areas on cut surface.

Figure 2: Scanner view showing multiple epidermal cysts in Fibroadenoma.

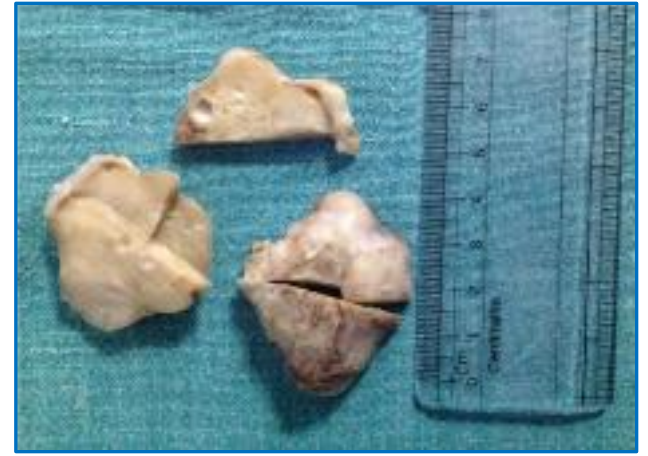

Fig. 1

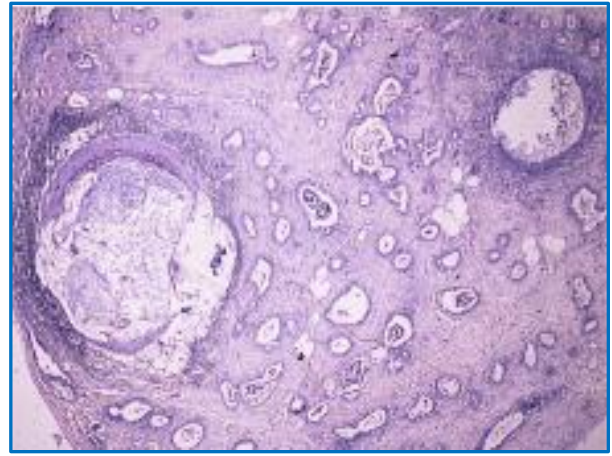

Fig. 2

Figure 3: H \& E stained section showing squamous metaplasia of one of the duct. (x40).

Figure 4: Epidermal cyst surrounded by chronic inflammatory cells in setting of fibroadenoma (H \& E) (x 40).

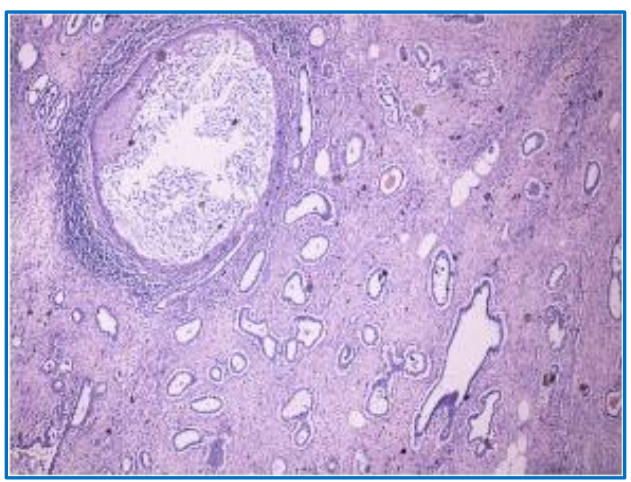

Fig. 3

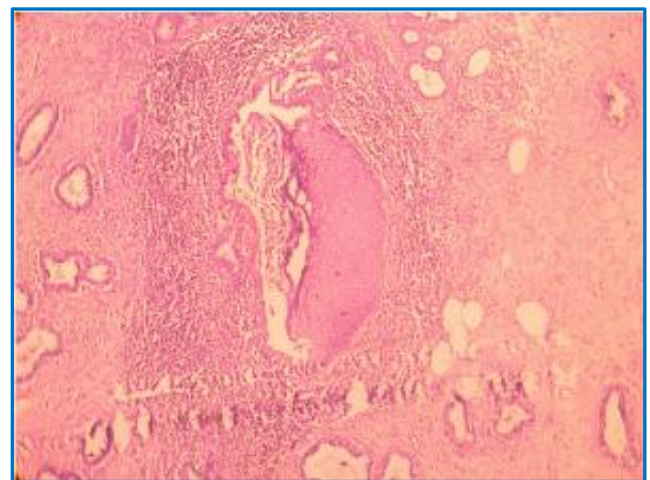

Fig. 4 


\section{CASE REPORT}

\section{AUTHORS: \\ 1. R. K. Chandrakar \\ 2. Chandni Krishnani \\ 3. Nidhi Rai \\ 4. Yogesh Pawde \\ 5. Manoj Malpani}

\section{PARTICULARS OF CONTRIBUTORS:}

1. Consultant Pathologist, Department of Pathology, Apollo BSR Hospitals, Bhilai, C.G.

2. Consultant Pathologist, Department of Pathology, Apollo BSR Hospitals, Bhilai, C.G.

3. Consultant Pathologist, Department of Pathology, Apollo BSR Hospitals, Bhilai, C.G.

FINANCIAL OR OTHER

COMPETING INTERESTS: None
4. Consultant Pathologist, Department of Pathology, Apollo BSR Hospitals, Bhilai, C.G.

5. Consultant Pathologist, Department of Pathology, Apollo BSR Hospitals, Bhilai, C.G.

\section{NAME ADDRESS EMAIL ID OF THE CORRESPONDING AUTHOR:}

Dr. Chandni Krishnani, 42-A, Cross Street-1,

Near Apollo BSR Hospitals,

Smriti Nagar, Bhilai.

E-mail: itschandnik@gmail.com

Date of Submission: 12/05/2015.

Date of Peer Review: 13/05/2015.

Date of Acceptance: 27/05/2015.

Date of Publishing: 04/06/2015. 